\title{
Natamycin and nisin to improve shelf life and minimize benzene generation in lemon soft drinks
}

\author{
Juliano GARAVAGLIA ${ }^{1,2^{*}}$, Laura Massochin Nunes PINTO ${ }^{1}$, Daiana de SOUZA ${ }^{1}$, Juliana de CASTILHOS ${ }^{1}$, \\ Rochele Cassanta ROSSI ${ }^{1}$, Isabel Cristina Kasper MACHADO ${ }^{1,2}$, Renata Cristina de Souza RAMOS ${ }^{1}$, \\ Denise Dumoncel Righetto ZIEGLER ${ }^{1}$
}

\begin{abstract}
Benzoic acids preservatives may be converted to benzene in soft drinks. The use of alternative antimicrobial compounds, specifically nisin and natamycin, would reduce benzene formation. Initially, doses of nisin and natamycin were tested against Lactobacillus plantarum lactic bacteria and Zygosaccharomyces bailii yeast. Using $167 \mathrm{UI} / \mathrm{mL}$ of nisin and $0.017 \% \mathrm{w} / \mathrm{v}$ of natamycin no microbial growth was reached on lemon-flavored soft drinks. The benzene formation was analyzed in a standard formulation ( $380 \mathrm{mg} / \mathrm{L}$ of sodium benzoate and $180 \mathrm{mg} / \mathrm{L}$ of potassium sorbate) and nisin and natamycn formulation ( $167 \mathrm{UI} / \mathrm{mL}$ of nisin and $0.017 \% \mathrm{w} / \mathrm{v}$ of natamycin). The soft drinks were stored without UV exposure at $20{ }^{\circ} \mathrm{C}$ and with UV sunlight exposure at $30^{\circ} \mathrm{C}$, for 120 days at PET bottles. The initial benzene content was $1.29 \mu \mathrm{g} / \mathrm{kg}$ for standard and $0.09 \mu \mathrm{g} / \mathrm{kg}$ for nisin and natamycin formulation; these values increased to $11.00 \mu \mathrm{g} / \mathrm{kg}$ and $0.18 \mu \mathrm{g} / \mathrm{kg}$, respectively. The sensory attributes did not differ from each formulation, either initially or after 120 days of storage. The lower benzene concentrations obtained using nisin and natamycin suggest that these compounds are attractive alternatives to benzoic acids, keeping the sensory quality and microbial stability during shelf life.
\end{abstract}

Keywords: natamycin; nisin; soft drinks; benzene; preservatives.

Practical application: Natamycin and nisin was used to produce a stable soft drink with sensory quality and less benzene.

\section{Introduction}

The manufacturing of carbonated soft drinks is a very large industry (Fabietti et al., 2001). Soft drinks are susceptible to microbial spoilage because their high carbon-to-nitrogen $(\mathrm{C} / \mathrm{N})$ ratio and low $\mathrm{pH}$ (3.5) allows the growth of acetic and lactic acid bacteria, molds, and yeasts (Belletti et al., 2007). Benzoic and sorbic acids have been used as preservatives in soft drinks (Arisseto et al., 2013), but by associated of benzoic acid to ascorbic acids can generate a benzene accumulation in soft drinks (Nyman et al., 2010). At low $\mathrm{pH}$, highly reactive hydroxyl radicals can form by an ascorbic acid-assisted pathway, catalyzed by iron $\left(\mathrm{Fe}^{3+}\right)$ and/or copper $\left(\mathrm{Cu}^{2+}\right)$ (Nyman et al., 2010). The hydroxyl radical is thought to react with benzoic acid to generate an unstable benzoic acid radical, which subsequently loses $\mathrm{CO}_{2}$ to form benzene (Nyman et al., 2010; International Council of Beverages Associations, 2006). Elevated benzene content of soft drinks was firstly detected by the industry in 1990-1991, especially with high heating and light exposure (International Council of Beverages Associations, 2006).

Natamycin and nisin, which are generally recognized as being safe (Kallinteri et al., 2013; Li et al., 2012) can be used of alternative to place of sodium benzoate and reduce the benzene formation (International Council of Beverages Associations, 2006; Nyman et al., 2010). The use of nisin is approved as an antimicrobial in food (Aouadhi et al., 2014). Secreted by Lactococcus lactis subsp. lactis, nisin is a hydrophobic, cationic polypeptide (Aouadhi et al., 2014) with more antimicrobial activity against Gram-negative bacteria (Kallinteri et al., 2013). Nisin can be used in litchi juices (Li et al., 2012), cheeses (Aly et al., 2012), beer and other beverages (Delves-Broughton, 2005).

Natamycin is a macrolide polyene antifungal, produced by the aerobic fermentation of Streptomyces natalensis (Tsiraki \& Savvaidis, 2014). Natamycin is a natural fungicide commonly employed in the food industry, especially for dairy products (Kallinteri et al., 2013). Because natamycin is very poorly absorbed, there is an adequate margin of safety in its current applications, and there is no concern for the induction of antimicrobial resistance (European Food Safety Authority, 2009).

This study evaluated the ability of antimicrobials natamycin and nisin to increase the shelf life, inhibit microbial growth and decrease benzene formation, compared to the preservative sodium benzoate in lemon-flavored soft drinks.

\section{Material and methods}

\subsection{Microorganisms and preservatives}

The yeast strain used as indicator strain in this study was Zygosaccharomyces bailii BCV 08, from the yeast collection of Laboratory of Mycology from Federal University of Rio Grande 
do Sul (UFRGS). The yeast was maintained in Potato Dextrose Agar (Acumedia, Lansing, MI, USA) and at $4{ }^{\circ} \mathrm{C}$. The bacteria strain used was Lactobacillus plantarum ATCC 8014 and was maintained in Orange Serum Agar (Acumedia) at $4{ }^{\circ} \mathrm{C}$.

The natamycin and nisin were commercial products, Natamax ${ }^{\circledR}$ and Nisaplin ${ }^{\circledR}$ respectively, obtained from Dupont ${ }^{\mathrm{min}}$ Danisco $^{\circledR}$ (Reigate, UK). Each $1 \mathrm{~g}$ of Nisaplin ${ }^{\circledR}$ contains approximately $2.5 \%$ $(\mathrm{w} / \mathrm{w})$ nisin $\left(10^{6} \mathrm{UI} / \mathrm{g}\right.$ of Nisaplin $\left.{ }^{\circledR}\right)$; Natamax ${ }^{\circledR}$ had a content of $50 \%(\mathrm{w} / \mathrm{w})$ of natamycin. Sodium benzoate and potassium sorbate were purchased from Emerald Kalama Chemical, LLC (Kalama, USA).

\subsection{Antimicrobial effects}

The effects of natamycin and nisin singly and combined were evaluated. For natamycin, three doses were tested: i) $0.017 \%(\mathrm{w} / \mathrm{v})$, ii) $0.025 \%(\mathrm{w} / \mathrm{v})$ and iii) $0.050 \%(\mathrm{w} / \mathrm{v})$. Nisin was used in the following doses: i) $167 \mathrm{IU} / \mathrm{mL}$, ii) $250 \mathrm{IU} / \mathrm{mL}$ and iii) $500 \mathrm{IU} / \mathrm{mL}$. So, to reach a nisin activity concentration of $500 \mathrm{IU} / \mathrm{mL}, 0.5 \mathrm{mg}$ of Nisaplin ${ }^{\circledR}$ was dissolved in $1 \mathrm{~mL}$. The doses of the natural preservatives were defined based on Brazilian food laws, the European Food Safety Authority (European Food Safety Authority, 2009) and information obtained from the suppliers of the commercial products.

The tests with antimicrobial agents were conducted on flat-bottomed 96-well microtiter plates (Steels et al., 2000). Starter cultures of Z. bailii ( 24 hours, $28{ }^{\circ} \mathrm{C}, 120 \mathrm{rev} / \mathrm{min}$ ) or L. plantarum were accurately diluted in YPD or MRS broth, respectively, to obtain an optical density $(600 \mathrm{~nm})$ of 0.004 to 0.008 , with approximately $10^{5} \mathrm{CFU} / \mathrm{mL}$, and then diluted $100 \mathrm{X}$ prior to inoculation. Aliquots of $20 \mu \mathrm{L}$ of inoculum were transferred to each well on a flat-bottomed 96-well microtiter plate, with $100 \mu \mathrm{L}$ of YPD or MRS broth and $80 \mu \mathrm{L}$ of preservative solution. The plates were capped, sealed and incubated for 5 days at $28^{\circ} \mathrm{C}$ (yeast culture) or $37^{\circ} \mathrm{C}$ (bacteria culture) and, after the optical density was measured at $600 \mathrm{~nm}$ (SpectraMax MI5, Molecular Devices, CA, USA). The positive control was performed in wells without preservative addition, and the negative control was performed without the microbial inoculum.

The effect of each preservative was evaluated by the decrease of the optical density at $600 \mathrm{~nm}$ value compared with the positive control, calculating the microbial inhibition index (\%). Also, the antimicrobial effect of nisin and natamycin were compared with traditional weak acids preservatives in soft drinks, using $180 \mathrm{mg} / \mathrm{L}$ of potassium sorbate and $380 \mathrm{mg} / \mathrm{L}$ sodium benzoate.

\subsection{Lemon soft drinks production and shelf life}

Lemon-flavored soft drinks were prepared aseptically in 600-mL PET bottles based on Brazilian legislation standard norms. Table 1 lists the specifications of the different formulations used in the study. The simple syrup was prepared with cane sugar solution in mineral carbonated water to obtain a final sugar value of $65^{\circ} \mathrm{Brix}$.

The bottles were stored using two different conditions: (i) $20 \pm 2{ }^{\circ} \mathrm{C}$ without light exposition (best condition) and (ii) $30 \pm 2^{\circ} \mathrm{C}$ with light exposition (critical condition). The storage
Table 1. Specifications of lemon soft drinks used in the tests. The values with same letters in the line are not significantly different according to Tukey's test (95\%).

\begin{tabular}{lcc}
\hline \multicolumn{1}{c}{ Parameter } & $\begin{array}{c}\text { Standard } \\
\text { formulation }\end{array}$ & $\begin{array}{c}\text { Formulation } \\
\text { with nisin and } \\
\text { natamycin }\end{array}$ \\
\hline Sugars $\left({ }^{\circ}\right.$ Brix) & $9.35 \pm 0.1^{\mathrm{a}}$ & $9.5 \pm 0.1^{\mathrm{a}}$ \\
Titratable acidity & $0.14 \pm 0.05^{\mathrm{a}}$ & $0.12 \pm 0.06^{\mathrm{a}}$ \\
$(\mathrm{g}$ of citric acid/L) & $2.97 \pm 0.04^{\mathrm{a}}$ & $3.03 \pm 0.05^{\mathrm{a}}$ \\
$\mathrm{pH}$ & $3.7 \pm 0.25^{\mathrm{a}}$ & $3.45 \pm 0.05^{\mathrm{a}}$ \\
Turbidity $(\mathrm{NTU})$ & $1.034 \pm 0.005^{\mathrm{a}}$ & $1.035 \pm 0.005^{\mathrm{a}}$ \\
Density $\left(\mathrm{g} / \mathrm{cm}^{3}\right)$ & $3.8 \pm 0.02^{\mathrm{a}}$ & $3.75 \pm 0.04^{\mathrm{a}}$ \\
Carbonic gas pressure $(\mathrm{v} / \mathrm{v})$ & 380 & - \\
Sodium benzoate $(\mathrm{mg} / \mathrm{L})$ & 180 & - \\
Potassium sorbate $(\mathrm{mg} / \mathrm{L})$ & - & 167 \\
Nisin $(\mathrm{UI} / \mathrm{mL})$ & - & 0.017 \\
Natamycin $(\%$ w/v) & & \\
\hline
\end{tabular}

conditions were performed according to typical shelf life used by retailers on Brazilian market. Therefore, as the benzene formation is accelerated by UV exposition (Nyman et al., 2010) and this effect could be assessed also.

The dosages of natamycin and nisin in the soft drink formulations were defined by primary experiments with indicator microorganisms. All results were compared with the control standard formulation of lemon soft drinks and the shelf life test was conducted under controlled temperature conditions during 120 days. The samples were collected four times during this period: (I) $S F O$ - shelf life start, (II) $S F 1$ - after 45 days, (III) SF2 - after 90 days, and (IV) SF3 - after 120 days, at shelf life ending. The composition, microbial stability and sensory quality of soft drinks were evaluated in each sample collected.

\subsection{Analytical procedures}

The membrane filtration method was used to count the viable cells in samples. $100 \mathrm{~mL}$ of lemon soft drink were mixed with $100 \mathrm{~mL}$ of $0.02 \%$ peptone water (Oxoid) and then filtered aseptically though membranes with pore sizes of $0.41 \mu \mathrm{m}$ and $0.80 \mu \mathrm{m}$ (Merck Millipore, Billerica, MA, USA) for bacteria and yeast/molds counter, respectively, as proposed by Akond et al. (2009). The membranes were disposed in Petri dishes containing Plate Count Agar (Acumedia) supplemented with 2,3,5-triphenyl-2H-tetrazolium chloride (TTC) to enumerate the active total bacteria and at $35^{\circ} \mathrm{C}$ for 48 hours. Orange Serum Agar (Acumedia) was used to enumerate the lactic bacteria $\left(25^{\circ} \mathrm{C}\right.$ for 120 hours) and Potato Dextrose Agar (Acumedia) and $28^{\circ} \mathrm{C}$ for 96 hours for yeast and molds couting. The results are expressed in logarithms of the number of colonies ( $\log \mathrm{CFU} / \mathrm{mL}$ ). To confirm the acid lactic bacteria, each colony growth was tested for catalase production (Mohd Adnan \& Tan, 2007).

The soft drinks were maintained for 30 minutes in an ultrasonic bath (Hanna Struments, São Paulo, Brazil) to eliminate de carbonic gas. The $\mathrm{pH}$ was measured using a $\mathrm{pH}$ meter (Hanna Instruments) equipped with a glass electrode; the total acidity $(\mathrm{g} / \mathrm{L}$ of citric acid), sugars ( ${ }^{\circ}$ Brix, refractometer; Instruterm, São Paulo, 
Brazil) and turbidity (NTU; Hanna Instruments) measurements were performed in triplicate following AOAC official methods (Association of Official Analytical Chemists, 2002).

Benzene was measured according to Arisseto et al. (2013) using headspace-solid phase microextraction and gas chromatography/mass spectrometry (HS-SPME-GC/MS). For the SPME, a $75-\mu \mathrm{m}$ fiber of CAR/PDMS was used at $40^{\circ} \mathrm{C}$. The GC/MS system consisted of a HP 6890 gas chromatograph (Agilent Technologies, Palo Alto, CA, USA) equipped with a mass spectrometer (MSD 5973; Agilent) and capillary column HP-INNOWAX of $60 \mathrm{~m} \mathrm{X} 0.25 \mathrm{~mm}$ X $0.25 \mu \mathrm{m}$ (Agilent). Helium was used as the carrier gas at a flow rate of $0.7 \mathrm{~mL} / \mathrm{min}$. The injector temperature was at $230^{\circ} \mathrm{C}$ and oven temperature program was started at $30^{\circ} \mathrm{C}$ (for $0.1 \mathrm{~min}$ ), then increased at $2{ }^{\circ} \mathrm{C} / \mathrm{min}$ to $40^{\circ} \mathrm{C}$ (5 min), and $12^{\circ} \mathrm{C} / \mathrm{min}$ to $200^{\circ} \mathrm{C}$. The quadrupole and ionization source were maintained at $150{ }^{\circ} \mathrm{C}$ and $230^{\circ} \mathrm{C}$, respectively.

\subsection{Sensory analysis}

The multiple comparison test was used, placing the natamycin and nisin formulations side by side of standard formulation (lemon soft drink with $180 \mathrm{mg} / \mathrm{L}$ of potassium sorbate and $380 \mathrm{mg} / \mathrm{L}$ sodium benzoate), used as control sample. A five-point scale was used, starting at moderately better than the standard (5) to moderately worse than the standard (1), as proposed by Lawless \& Heymann (2010). The test was realized by an expert panel $(n=15)$, trained to identify the sensory attributes of soft drinks. The assessors evaluated four different sensory attributes important to sensory quality of soft drinks: sweet flavor, acid flavor, bitterness and chemical-type flavor notes. Sensory analyzes were carried out in a climatized $\left(22^{\circ} \mathrm{C}\right)$ individual cabins, and evaluated under white light, thereby ensuring comfort and privacy for the assessors.

The samples $\left(50 \mathrm{~mL}\right.$ of lemon soft drinks at $\left.8^{\circ} \mathrm{C}\right)$ were coded and presented randomly to the assessors. Soft drinks samples were used in pre-testing panel-test sessions to let the assessors familiarize with the products under investigation, the scale used and the terminology related. Those sessions were also used to standardize panel's attributes definitions and assessors perception.

\subsection{Statistical analysis}

The results were subjected to one-way ANOVA test for significant differences between the different time and conditions of soft drinks storage, also in sensory tests analysis. When significance was reached, Tukey's (HSD) post-hoc test (with a confidence interval of 95\%) was performed. These analyses were performed using the Statistica 7.0 software package (Statsoft, Tulsa, OK, USA) and all the experiments were performed in triplicate.

\section{Results and discussion}

\subsection{Antimicrobial effect of nisin and natamycin}

The natamycin and nisin effect against $Z$. bailii and L. plantarum cultures was examined. In soft drinks, for selective conditions and composition (low $\mathrm{pH}$ and high sugar content), the growth of lactic acid bacteria and yeasts and molds is favored (Ndagijimana et al., 2004; Akond et al., 2009; Fitzgerald et al.,
2004; Ilaslan et al., 2014). Nevertheless, even at minor dosage of natamycin and nisin, was possible verify a great inhibitory index. The Figure 1 shows the inhibitory index (\%) of the preservatives against spoilage microorganisms.

Initially, the maximal recommended doses of both preservatives were used $(0.1 \% \mathrm{w} / \mathrm{v}$ of natamycin and $500 \mathrm{UI} / \mathrm{mL}$ of nisin). Then, half reduction of these doses, the inhibition index was maintained (Figure 1) and reduced again. The utilization of lower doses is advantageous to decrease the formulation costs and the negative sensorial characteristics produced in soft drinks. As a result, the minimal doses used $(0.017 \% \mathrm{w} / \mathrm{v}$ of natamycin and $167 \mathrm{UI} / \mathrm{mL}$ of nisin), were sufficient to controlling the growth of standard microorganisms.

The natamycin is considered to be a fungicide with a dose-dependent effect (Kallinteri et al., 2013); as a result, for all the tested doses, the yeasts growth was completely inhibited (Figure 1). Natamycin acting directly on the cell wall (te Welscher et al., 2008) and is commonly used in cheeses (Ollé Resa et al., 2014) and in beverages as soft drinks (Nyman et al., 2010).

Regarding the bacteria control, the maximum inhibition average of $L$. plantarum, achieved with $0.1 \%(\mathrm{w} / \mathrm{v})$ natamycin, was approximately $25 \%$ (Figure 1 ). L. plantarum was completely inhibited (100\%) only with nisin employment even with the low level tested. The total inhibition (100\%) of yeasts was only observed for the application of natamycin, at all tested doses. This effect is due to the action spectrum of the preservatives tested (Nyman et al., 2010). On the other hand, the data suggested that a total inhibition (100\%) of microorganisms was possible by the simultaneous application of natamycin and nisin.

Nisin has a related effect with food composition and its utilization is recommended to improve the quality and stability of innumerable foods (Aly et al., 2012). For example, in Port Salut cheese, a film of natamycin $(0.027 \% \mathrm{w} / \mathrm{w})$ inhibits the growth of Saccharomyces cerevisiae, and a film of nisin $(272 \mathrm{UI} / \mathrm{g})$ and natamycin $(0.027 \% \mathrm{w} / \mathrm{w})$ controls the growth of Listeria innocua, allowing the consumer to receive a safer

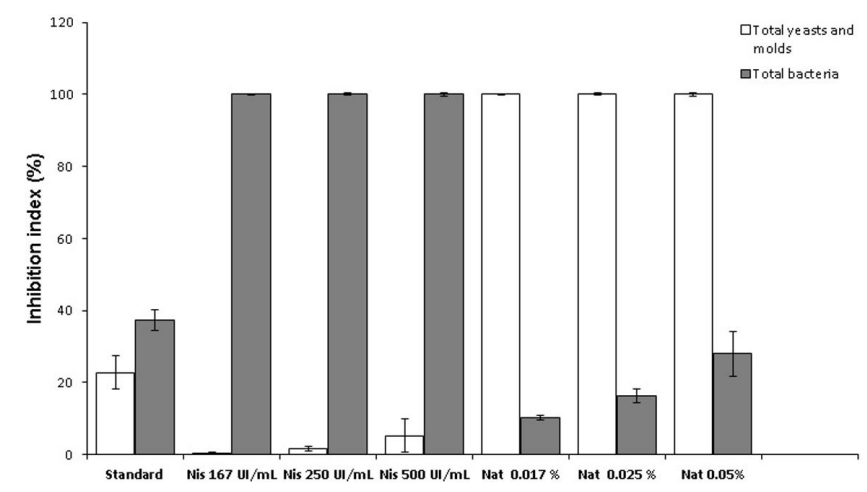

Figure 1. Inhibition index (\%) of microorganisms growth test on microplates using various nisin doses (167 UI/mL: Nis 167; $250 \mathrm{UI} / \mathrm{mL}$ : Nis 250 and $500 \mathrm{UI} / \mathrm{mL}$ : Nis500) and natamycin doses (0.017\%: Nat0.017; 0.025\%: Nat0.025 and 0.050\%: Nat0.050) and Standard (180 mg/L of potassium sorbate and $380 \mathrm{mg} / \mathrm{L}$ sodium benzoate). The standard error bars were calculated using triplicate testing. 
product (Ollé Resa et al., 2014). To control the growth of lactic bacteria in ale beer, a minimum of $37.5 \mathrm{mg} / \mathrm{mL}$ of nisin is required (Delves-Broughton, 2005).

\subsection{Microbiological changes during shelf life}

Soft drinks produced were considered stable to microbial contaminations of lactic bacteria, molds and yeasts, even after 120 days and for both tested conditions. For the shelf life, were applied the minimal doses of natural preservatives $(167 \mathrm{UI} / \mathrm{mL}$ of nisin and $0.017 \%$ of natamycin). The Figure 2 shows the effect of each preservative against bacteria and yeasts after 120 days.

The microbial population in lemon soft drinks after shelf life was significantly reduced comparing of $20^{\circ} \mathrm{C}$ and $30^{\circ} \mathrm{C}$ of storage temperature in both formulations (Figure 2). Using sodium benzoate and potassium sorbate, at the end of the shelf life, $2 \log$ CFU/100 mL of yeasts and molds, $2 \log$ CFU/100 mL of lactic bacteria and $5 \log \mathrm{CFU} / 100 \mathrm{~mL}$ of active bacteria were observed. Using the formulation with nisin and natamycin the microbial growth was preserved below $1 \log$ CFU/100 mL, for all conditions tested.

When using nisin and natamycin, the microbial stability was better than the formulation with sodium benzoate and potassium sorbate, indicating that its use may extend the shelf life of soft drinks. Microbial growth was shown even using sodium benzoate $(380 \mathrm{mg} / \mathrm{L})$ and potassium sorbate $(180 \mathrm{mg} / \mathrm{L})$ (Figure 2). Maximal levels permitted by Brazilian laws $(500 \mathrm{mg} / \mathrm{L}$ of sodium benzoate and $200 \mathrm{mg} / \mathrm{L}$ of potassium sorbate) must be applied combined and can inhibits yeast, molds and bacteria growth (World Health Organization, 2000).

The antimicrobial action of weak-acid preservatives is $\mathrm{pH}$-dependent, and it has been established that they are much more active in acidic environments (Martorell et al., 2007). Yeasts show tolerance to low $\mathrm{pH}$ and are associated to spoilage of soft drinks (Martorell et al., 2007). For this reason, the yeast growth would be achieved even using benzoic and sorbic acid. This $\mathrm{pH}$ effect can be avoided using alternative preservatives such as nisin and natamycin. Nisin is very stable at $\mathrm{pH}$ range of 3.0 to 3.5 (Delves-Broughton, 2005). Natamycin also is stable at

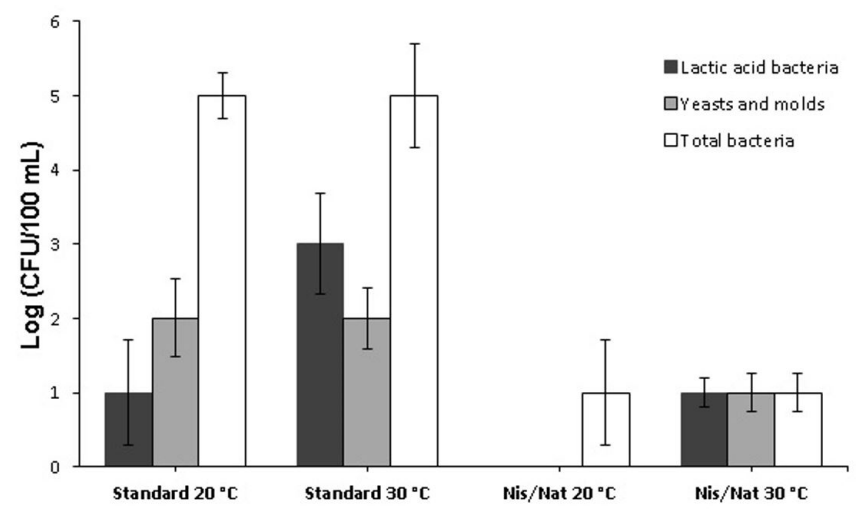

Figure 2. Growth of microorganisms from formulations of lemon soft drinks after 120 days using standard formulation (potassium sorbate and sodium benzoate) and formulation containing nisin and natamycin. The standard error bars were calculated based on triplicate testing. low $\mathrm{pH}$ values, but its activity can be reduced by low $\mathrm{pH}$ value of 3.0 (Tsiraki \& Savvaidis, 2014). The lemon-flavored soft drinks used have a $\mathrm{pH}$ value about 3.0, which can maintain the stability of nisin and natamycin.

High levels of yeasts could lead to alterations and decrease the quality of soft drinks (Belletti, et al., 2007). Moreover, the high sugars and salts concentration in soft drinks favor osmophilic yeast development, such as Zygosaccharomyces sp., Rhodototula sp. and Pichia sp. (Pribylova et al., 2003). The common yeasts alteration is characterized by substantial carbonic gas production, which causes PET packaging deformation, sediment production and a fermentative aroma bouquet (Loureiro \& Querol, 1999). The formation of carbonic gas is not a health risk but causes visual damage to the package and increases economic losses for the industry (Ndagijimana et al., 2004).

Concerning the condition at $30^{\circ} \mathrm{C}$ and after 120 days, was reached a total level of $3 \log \mathrm{CFU} / 100 \mathrm{~mL}$ for lactic bacteria, $5 \log$ CFU/100 mL for active bacteria and $2 \log$ CFU/100 mL for yeasts. For the natamycin and nisin soft drink, the microbial growth was not detected at $20^{\circ} \mathrm{C}$, but at $30^{\circ} \mathrm{C}, 1 \log \mathrm{CFU} / 100 \mathrm{~mL}$ was observed for the bacteria and yeast counts. The temperature may have increased yeast and bacterial growth in both lemon soft drink formulations. On other hand, the antimicrobial activity of natamycin and nisin is very stable even to increasing temperature (Ollé Resa et al., 2014; Delves-Broughton, 2005).

\subsection{Sensory and composition evaluation}

The total acidity, $\mathrm{pH}$, sugars value and turbidity were evaluated as these parameters represent important factors for control the soft drink quality. All parameters were initially within acceptable legal and quality limits for lemon-flavored soft drinks. Significant differences were not observed for sugars values when comparing the beginning and the ending of shelf life for both formulations and conditions tested (Table 2).

An increase of acidity and $\mathrm{pH}$ value decrease, from 45 days of storage, was observed (Figure 3A and 3B). The $\mathrm{pH}$ increases slightly between 45 and 90 days, and was reduced after 120 days of storage (Table 2). This effect was significant (95\%) when compared the acidity and $\mathrm{pH}$ level from the initial to the end of storage time (120 days), for all formulations and conditions tested. The enhancement of acidity and $\mathrm{pH}$ decline were also verified in standard formulation, confirming that the use of nisin and natamycin not modify these lemon soft drinks parameters.

An increase on acidity may have been due to chemical equilibrium modifications inside the PET bottles (Nyman et al., 2010). During the storage, precipitation and dissolving of salts (Dias et al., 2011) and even the incorporation of oxygen during bottling and storage (Arisseto et al., 2013) are common, modifying their compositions and $\mathrm{pH}$ value. $\mathrm{PET}$ bottle permit gas exchanges and allows light to pass through (Katoch et al., 2010), which would cause alterations on $\mathrm{pH}$ and acidity levels (Nyman et al., 2010).

The sensory characteristics were measured using the multiple comparison test. The formulation with nisin and natamycin was considered equal to formulation with sodium benzoate 
Table 2. Quality parameters and benzene accumulation in lemon soft drinks formulations during shelf life at different conditions. The values with same letters in the line are not significantly different according to Tukey's test (95\%).

\begin{tabular}{|c|c|c|c|c|c|c|c|c|}
\hline \multirow{3}{*}{ Parameter } & \multicolumn{4}{|c|}{ Standard formulation } & \multicolumn{4}{|c|}{ Nisin and natamycin formulation } \\
\hline & \multicolumn{2}{|c|}{0 days } & \multicolumn{2}{|c|}{120 days } & \multicolumn{2}{|c|}{0 days } & \multicolumn{2}{|c|}{120 days } \\
\hline & $20^{\circ} \mathrm{C}$ & $30^{\circ} \mathrm{C}$ & $20^{\circ} \mathrm{C}$ & $30^{\circ} \mathrm{C}$ & $20^{\circ} \mathrm{C}$ & $30^{\circ} \mathrm{C}$ & $20^{\circ} \mathrm{C}$ & $30^{\circ} \mathrm{C}$ \\
\hline Sugars $\left({ }^{\circ}\right.$ Brix $)$ & $9.6 \pm 0.15^{\mathrm{a}}$ & $9.6 \pm 0.1^{\mathrm{a}}$ & $9.8 \pm 0.12^{\mathrm{a}}$ & $9.8 \pm 0.15^{\mathrm{a}}$ & $9.5 \pm 0.1^{\mathrm{a}}$ & $9.5 \pm 0.1^{\mathrm{a}}$ & $9.9 \pm 0.25^{\mathrm{a}}$ & $9.6 \pm 0.15^{\mathrm{a}}$ \\
\hline $\mathrm{pH}$ & $3.36 \pm 0.005^{\mathrm{a}}$ & $3.14 \pm 0.015^{\mathrm{b}}$ & $3.29 \pm 0.025^{\mathrm{d}}$ & $3.06 \pm 0.01^{\mathrm{d}}$ & $3.07 \pm 0.01^{\mathrm{d}}$ & $3.06 \pm 0.01^{\mathrm{d}}$ & $3.02 \pm 0.02^{\mathrm{e}}$ & $2.93 \pm 0.005^{\mathrm{f}}$ \\
\hline $\begin{array}{l}\text { Benzene } \\
(\mu \mathrm{g} / \mathrm{kg})\end{array}$ & $1.29 \pm 0.1^{\mathrm{c}}$ & $1.29 \pm 0.1^{c}$ & $4.0 \pm 0.01^{\mathrm{b}}$ & $11.0 \pm 0.25^{\mathrm{a}}$ & $0.09 \pm 0.01^{\mathrm{e}}$ & $0.09 \pm 0.01^{\mathrm{e}}$ & $0.18 \pm 0.05^{\mathrm{e}}$ & $0.7 \pm 0.12^{\mathrm{d}}$ \\
\hline
\end{tabular}
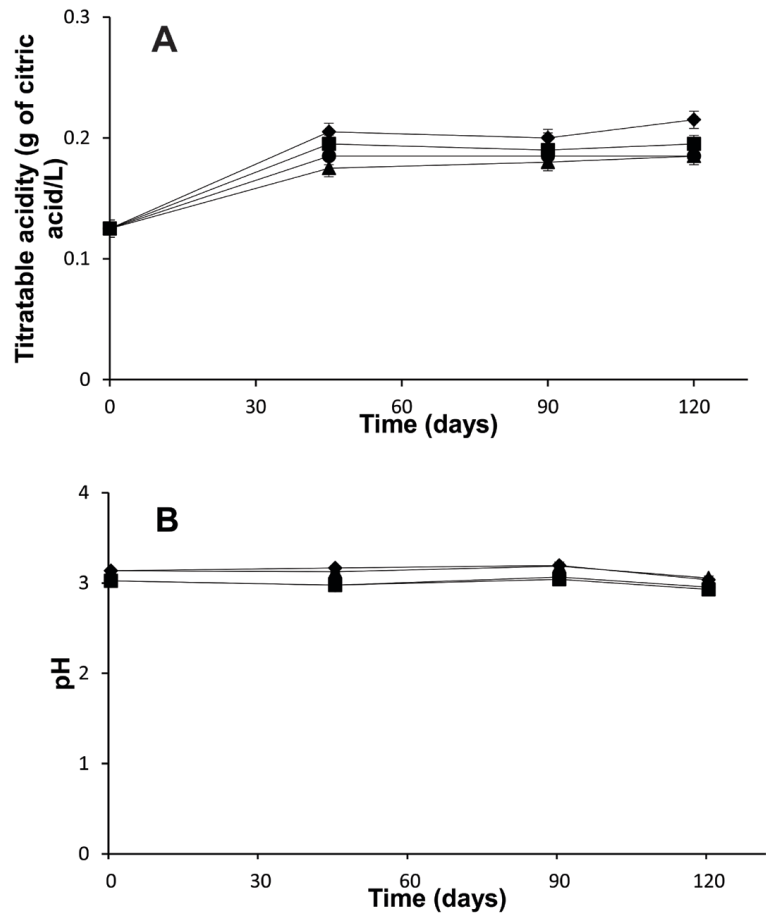

Figure 3. Evaluation of lemon soft drinks compositions at beginning of shelf life (SF0), 45 days (SF1), 90 days (SF2) and 120 days (SF3). A: total acidity; B: pH. Squares: $20^{\circ} \mathrm{C}$, formulation with nisin and natamycin; diamonds: $20^{\circ} \mathrm{C}$, formulation with sodium benzoate and potassium sorbate; circles: $30^{\circ} \mathrm{C}$, formulation with nisin and natamycin; triangles: $30{ }^{\circ} \mathrm{C}$, formulation with sodium benzoate and potassium sorbate. The standard error bars were calculated based on triplicate testing.

and potassium sorbate. These results were identical for all the sensory attributes investigated (bitterness, sweetness, acidity and chemical-type notes). These findings demonstrate that nisin and natamycin did not alter significantly the lemon soft drink flavor quality, including at the shelf life ending.

\subsection{Benzene formation}

The use of benzoic acid as a preservative in soft drinks directly leads to the formation of benzene (Nyman et al., 2010). Thus, the use of natural preservatives may be a strategy to minimize benzene generation (Belletti et al., 2007). Comparing the formulation with nisin and natamycin and the standard formulation, the benzene formation was significantly reduced when using these alternative preservatives. For the standard formulation, the storage time and temperature had a direct effect on the benzene formation (Table 2).

From the start of the shelf life (SF0), after 120 days and at $20^{\circ} \mathrm{C}$, an increase of approximately $210 \%$ in the benzene level was reached (Table 2); however, at $30{ }^{\circ} \mathrm{C}$ this enhancement was $750 \%$, and the quantity of benzene detected was $4 \mu \mathrm{g} / \mathrm{kg}$ and $11 \mu \mathrm{g} / \mathrm{kg}$, respectively. Higher temperatures can lead to an increase in benzene formation in soft drinks (Arisseto et al., 2013), which is a compound with great toxicity for humans (Türkoğlu, 2007), and its level is regulated (International Council of Beverages Associations, 2006).

The initial benzene concentration in the standard formulation was $1.29 \mu \mathrm{g} / \mathrm{kg}$ (Table 2). Using natamycin and nisin, at the beginning of the shelf life, $0.09 \mu \mathrm{g} / \mathrm{kg}$ of benzene was detected, and, at the end, values of $0.18 \mu \mathrm{g} / \mathrm{kg}$ at $20^{\circ} \mathrm{C}$ and $0.7 \mu \mathrm{g} / \mathrm{kg}$ at $30{ }^{\circ} \mathrm{C}$ were detected.

\section{Conclusions}

Natamycin and nisin can be used to preserve the quality of lemon-flavored soft drinks. At doses of $0.017 \%$ (w/v) of natamycin and $167 \mathrm{UI} / \mathrm{mL}$ of nisin, it was possible to inhibit the growth of L. plantarum and Z. bailii cultures, and even after 120 days, using these same doses, the lemon soft drinks remained stable. Besides the lemon soft drink produced offered good quality with a composition that adhere legal and technological specifications. Using natamycin and nisin, the soft drink produced results in lower benzene formation while maintaining the sensory and microbiological quality. Therefore, the natamycin and nisin concomitant association provides an alternative to the use benzoic and sorbic acid.

\section{Acknowledgements}

The authors thank the Financiadora de Estudos e Projetos (FINEP) of the Brazilian Government for financial support, Dr. Patricia Valente (UFRGS) for yeast strain tested and Fruki Beverages S.A. for the lemon soft drinks samples. 


\section{References}

Akond, M. A., Alam, S., Hasan, S. M. V., Mubassara, S., Uddin, S. N., \& Shirin, M. (2009). Bacterial contaminants in carbonated soft drinks sold in Bangladesh markets. International Journal of Food Microbiology, 130(2), 156-158. http://dx.doi.org/10.1016/j. ijfoodmicro.2009.01.014. PMid:19232446.

Aly, S., Floury, J., Piot, M., Lortal, S., \& Jeanson, S. (2012). The efficacy of nisin can drastically vary when produced in situ in model cheeses. Food Microbiology, 32(1), 185-190. http://dx.doi.org/10.1016/j. fm.2012.06.001. PMid:22850391.

Aouadhi, C., Rouissi, Z., Mejri, S., \& Maaroufi, A. (2014). Inactivation of Bacillus sporothermodurans spores by nisin and temperature studied by design of experiments in water and milk. Food Microbiology, 38, 270-275. http://dx.doi.org/10.1016/j.fm.2013.10.005. PMid:24290651.

Arisseto, A. P., Vicente, E., Furlani, R. P. Z., Pereira, A. L. D., \& Figueiredo Toledo, M. C. (2013). Development of a headspace-solid phase microextraction-gas chromatography/mass spectrometry (HSSPME-GC/MS) method for the determination of benzene in soft drinks. Food Analytical Methods, 6(5), 1379-1387. http://dx.doi. org/10.1007/s12161-012-9554-8.

Association of Official Analytical Chemists - AOAC. (2002). Official methods of analysis of AOAC international (17. ed.). Maryland: Association of Analytical Communities.

Belletti, N., Kamdem, S. S., Patrignani, F., Lanciotti, R., Covelli, A., \& Gardini, F. (2007). Antimicrobial activity of aroma compounds against Saccharomyces cerevisiae and improvement of microbiological stability of soft drinks as assessed by logistic regression. Applied and Environmental Microbiology, 73(17), 5580-5586. http://dx.doi. org/10.1128/AEM.00351-07. PMid:17616627.

Delves-Broughton, J. (2005). Nisin as a food preservative. Food Australia, 57, 525-527.

Dias, L. G., Peres, A. M., Barcelos, T. P., Sá Morais, J., \& Machado, A. A. S. C. (2011). Semi-quantitative and quantitative analysis of soft drinks using an electronic tongue. Sensors and Actuators. B, Chemical, 154(2), 111-118. http://dx.doi.org/10.1016/j.snb.2010.01.005.

European Food Safety Authority - EFSA. (2009). EFSA Panel on Food Additives and Nutrient Sources added to Food (ANS); Scientific Opinion on the use of natamycin (E 235) as a food additive. EFSA Journal, 7, 1-25.

Fabietti, F., Delise, M., \& Bocca, A. P. (2001). Investigation into the benzene ad toluene content of soft drinks. Food Control, 12(8), 505509. http://dx.doi.org/10.1016/S0956-7135(01)00041-X.

Fitzgerald, D. J., Stratford, M., Gasson, M. J., \& Narbad, A. (2004). The potential application of vanilin in preventing yeast spoilage of soft drinks and fruit juices. Journal of Food Protection, 67(2), 391-395. http://dx.doi.org/10.4315/0362-028X-67.2.391. PMid:14968976.

Ilaslan, K., Boyaci, I. H. \& Topcu, A. (2014). Rapid analysis of glucose, fructose and sucrose contents of commercial soft drinks using Raman spectroscopy. Food Control, 48, 56-61. http://dx.doi.org/10.1016/j. foodcont.2014.01.001.

International Council of Beverages Associations - ICBA. (2006). ICBA Guidance Document to Mitigate the Potential for Benzene Formation in Beverages (p. 26). London: The British Soft Drinks Association Ltd.

Kallinteri, L. D., Kostoula, O. K., \& Savvaidis, I. N. (2013). Efficacy of nisin and/or natamycin to improve the shelf-life of Galotyri cheese. Food Microbiology, 36(2), 176-181. http://dx.doi.org/10.1016/j. fm.2013.05.006. PMid:24010596.
Katoch, S., Sharma, V., \& Kundu, P. P. (2010). Water sorption and diffusion through saturated polyester and their nanocomposites synthesized from glycolyzed PET waste with varied composition. Chemical Engineering Science, 65(15), 4378-4387. http://dx.doi. org/10.1016/j.ces.2010.03.050.

Lawless, H. T., \& Heymann, H. (2010). Sensory evaluation of food: principles and practices (2. ed.). New York: Springer.

Li, H., Zhao, L., Wu, J., Zhang, Y., \& Liao, J. (2012). Inactivation of natural microorganisms in litchi juice by high-pressure carbon dioxide combined with mild heat and nisin. Food Microbiology, 30(1), 139145. http://dx.doi.org/10.1016/j.fm.2011.10.007. PMid:22265294.

Loureiro, V., \& Querol, A. (1999). The prevalence and control of spoilage yeasts in foods and beverages. Trends in Food Science \& Technology, 10(11), 356-365. http://dx.doi.org/10.1016/S0924-2244(00)00021-2.

Martorell, P., Stratford, M., Steels, H., Fernández-Espinar, M. T., \& Querol, A. (2007). Physiological characterization of spoilage strains of Zygosaccharomyces bailii and Zygosaccharomyces rouxii isolated from high sugar environments. International Journal of Food Microbiology, 114(2), 234-242. http://dx.doi.org/10.1016/j. ijfoodmicro.2006.09.014. PMid:17239464.

Mohd Adnan, A. F., \& Tan, I. K. (2007). Isolation of lactic acid bacteria from Malaysian foods and assessment of the isolates for industrial potential. Bioresource Technology, 98(7), 1380-1385. http://dx.doi. org/10.1016/j.biortech.2006.05.034. PMid:16872826.

Ndagijimana, M., Belletti, N., Lanciotti, R., Guerzoni, M. E., \& Gardini, F. (2004). Effect of aroma compounds on the microbial stabilization of orange-based soft drinks. Journal of Food Science, 69, 20-24.

Nyman, P. J., Wamer, W. G., Begley, T. H., Diachenko, G. W., \& Perfetti, G. A. (2010). Evaluation of accelerated UV and thermal testing for benzene formation in beverages containing benzoate and ascorbic acid. Journal of Food Science, 75(3), 263-267. http://dx.doi. org/10.1111/j.1750-3841.2010.01536.x. PMid:20492277.

Ollé Resa, C. P., Gerschenson, L. N., \& Jagus, R. J. (2014). Natamycin and nisin supported on starch edible films for controlling mixed culture growth on model systems and Port Salut cheese. Food Control, 44, 146-151. http://dx.doi.org/10.1016/j.foodcont.2014.03.054.

Pribylova, L., De Montigny, J., Potier, S., \& Sychrová, H. (2003). Physiological properties of the osmotolerant yeast Zygosaccharomyces rouxii. Microbiological Methods, 55, 481-484.

Steels, H., James, S. A., Roberts, I. N., \& Stratford, M. (2000). Sorbic acid resistance: the inoculum effect. Yeast, 16(13), 1173-1183. http://dx.doi.org/10.1002/1097-0061(20000930)16:13<1173::AIDYEA617>3.0.CO;2-8. PMid:10992281.

te Welscher, Y. M., ten Napel, H. H., Balagué, M. M., Souza, C. M., Riezman, H., de Kruijff, B., \& Breukink, E. (2008). Natamycin blocks fungal growth by binding specifically to ergosterol without permeabilizing the membrane. The Journal of Biological Chemistry, 283(10), 6393-6401. http://dx.doi.org/10.1074/jbc.M707821200. PMid:18165687.

Tsiraki, M. I., \& Savvaidis, I. S. (2014). Citrus extract or natamycin treatments on "Tzatziki" - A traditional Greek salad. Food Chemistry, 142, 416-422. http://dx.doi.org/10.1016/j.foodchem.2013.07.087. PMid:24001860.

Türkoğlu, S. (2007). Genotoxicity of five food preservatives tested on root tips of Allium cepa L. Mutation Research, 626(1-2), 4-14. http://dx.doi.org/10.1016/j.mrgentox.2006.07.006. PMid:17005441.

World Health Organization - WHO. (2000). Benzoic acid and sodium benzoate (p. 52) Geneva: United Nations Environment Programme. 